\title{
BANKING SOUNDNESS INDEX FOR TURKEY: THE PRINCIPAL COMPONENT ANALYSIS APPROACH
}

\author{
Türkiye İçin Bankacılık Sağlamlık Endeksi: Temel Bileşen Analizi Yaklaşımı
}

\section{Furkan YILDIRIM*}

\section{Keywords:}

Banking Soundness

Index, Financial

Stability, Principal

Component Analysis.

JEL Codes:

G21, G32, G33

Anahtar Kelimeler:

Bankacılık Sağlamlık

Endeksi, Finansal

İstikrar, Temel Bileşen

Analizi.

JEL Kodları:

G21, G32, G33

\begin{abstract}
This study aims to generate a banking soundness index by utilizing endogenous variables specific to banks in order to measure the banking sector's financial soundness. The core set of the financial stability index of the International Monetary Fund (IMF) is taken as the basis and the calculations of the proposed index are made with the quarterly data over the period 2007:Q22020:Q3. The variables in the sub-indicators are standardized using the minmax normalization technique. The principal component analysis method is employed on the standardized data. According to the results of the principal component analysis, variables are categorized into two main components. A strong relationship exists between profitability and liquidity ratios in the first principal component. In the second principal component, it is observed that market risk and certain capital adequacy ratios are associated with each other. The index reached its highest level in 2007:Q2. It is observed to reach its lowest levels in 2015:Q3 and 2020:Q1. It is seen that the calculated banking soundness index complies with the evaluations about the banking sector included in the financial stability reports published by the Central Bank of the Republic of Turkey (CBRT).
\end{abstract}

\section{$\ddot{O} \mathbf{z}$}

$\mathrm{Bu}$ çalışmada, bankacılık sektörü finansal sağlamlığının ölçülebilmesi için bankalara özgü içsel değişkenler kullanılarak bankacılık sağlamlık endeksi oluşturmak amaçlanmıştır. Çalışmada, Uluslararası Para Fonu'nun (IMF) finansal istikrar endeksi çekirdek seti temel alınmış ve önerilen endeksin hesaplamaları üçer aylık verilerle 2007: Q2 ile 2020: Q3 dönem aralığında yapılmıştır. Alt göstergelerde yer alan değişkenler min-max normalizasyon tekniği ile standardize edilmiştir. Standardize edilen verilere temel bileşen analizi yöntemi kullanılmıştır. Temel bileşen analizi sonuçlarına göre değişkenler iki temel bileşene ayrılmıştır. Birinci temel bileşende kârlılık ve likidite oranları güçlü bir ilişki içerisinde olduğu görülmüştür. İkinci temel bileşende ise piyasa riski ve bazı sermaye yeterlilik oranları ilişki içerisinde olduğu gözlemlenmiştir. Endeks 2007 yılı ikinci çeyreğinde en yüksek seviyesine ulaşmıştır. En düşük seviyesine ise 2015 üçüncü çeyreğinde ve 2020 ilk çeyreğinde geldiği görülmüştür. Hesaplanan bankacılık sağlamlık endeksi Türkiye Cumhuriyet Merkez Bankası'nın (TCMB) yayımladığı finansal istikrar raporlarında yer alan bankacılık sektörü ile ilgili değerlendirmelerle örtüştüğü görülmektedir.

\footnotetext{
* Lecturer Dr., Akdeniz University, Faculty of Applied Sciences, Department of Banking and Finance, furkanyildirim@akdeniz.edu.tr, ORCID: 0000-0002-0646-8638
} 


\section{Introduction}

The banking sector constitutes a large portion of the financial markets and serves as a bridge between the financial markets and the real sector. The sound and stable structure of the banking sector ensures efficient resource usage in the economy as well as the proper management and distribution of risks. The financial soundness of a bank indicates the capabilities of its capital adequacy, asset quality, liquidity, and profitability to cope with adverse market conditions (Cihak, 2007; Pukhov, 2013). Therefore, measuring the soundness of the banking sector is crucial to generate a robust financial structure in the presence of shocks that may occur in the economy.

The most overall definition of financial soundness is the ability of banks to maintain their activities in a stable manner (Koç and Karahan, 2017, p. 148). In other words, financial soundness provides information regarding whether or not the banking system has sufficient capital level and the ability of the banking sector to fulfill its obligations (Sanar and Kara, 2016, p. 114). Financial soundness indicators are of the current financial health and soundness of financial institutions in a country and their corporate and household counterparts; they are calculated to assist in evaluating and monitoring the strengths and weaknesses of financial systems in order to increase financial stability, and especially, reduce the possibility of financial system failure (International Monetary Fund [IMF], 2006).

There is no generally accepted analytical framework for measuring financial soundness in the international literature. The IMF has developed a financial soundness indicator set in order to evaluate the strengths and weaknesses of the financial system. As a result of the survey studies conducted on the member countries, indicators have been prepared as of June 2001 in two groups such as the core and additional sets (IMF, 2001). For Turkey, the Banking Regulatory and Supervisory Agency began to develop performance indexes consisting of indicators of the banking sector in 2004. In 2005, however, the CBRT began to conduct studies on the core set of financial soundness index (Varlık and Varlık, 2016, p. 547).

No clear definition of the banking soundness index exists in the international literature and the lack of tendency towards calculation in the studies is observed in this field. This study is conducted based on the problem regarding the extent to which financial indicators would be used to generate the banking soundness index and whether or not such index would be able to identify stable and unstable periods in the Turkish economy. This study aims to generate a banking soundness index for Turkey by taking into account the core set of financial soundness indicators published by the IMF. The variables in the IMF's indicator set are used in the study since they provide information on the extent to which the existing vulnerabilities in the system are formed and developed over time and are highly applicable. Besides, it aims to reveal the directions and degrees of the relationships among the variables included in the sub-indicators.

The results of the study are crucial in terms of developing an index by using a common set of indicators for countries, enabling comparisons among the countries, and guiding policymakers throughout the improvement of regulation and auditing activities that would uphold the soundness of the financial structure of the sector. Furthermore, upon examining the literature regarding the subject, it is seen that only a few studies that investigated the factors that determine the soundness of the banking sector for Turkey exist. It is also thought that this study would contribute to the literature regarding this subject on which quite a few studies were conducted. In the study, responses to certain questions are sought. Study questions are as 
follows: (1) Can the index reflect the periodic movements experienced in Turkey as of the period during which it has been calculated? (2) Can it accurately determine the financial situation of Turkey's banking sector along with the sub-indicators? In order to respond to these questions, the quarterly data obtained over the period 2007- 2020 were utilized in the study. The variables in the sub-indicators are standardized with the min-max normalization technique and the banking soundness index is created employing the principal component analysis method. Although ethics committee approval as well as legal/private permission has not been required, research and publication ethics are complied with in the study.

The study consists of six sections including introduction and conclusion. In the second section, a literature review on the banking soundness index is presented. In the third section, the principal component analysis method, which is the method of the study, is explained. In the fourth section, the dataset utilized in the study is explained. In the fifth section, the findings obtained from the analyses are presented. In the last section, results and limitations are presented.

\section{Literature Review}

Financial institutions are critical to the success of the country's economy, but obviously there are not the only factor regarding the success of countries' economies. Central banks tend to concentrate more on market segments in their financial stability reports, and the indicator sets formed by international institutions are not seen to be widely used (Gadanecz and Jayaram, 2009 , p. 372). Measuring the financial stability and soundness of banks is a complex process involving a significant number of multidimensional criteria. Therefore, the selection of evaluation techniques to be employed in the relevant banking sector is quite crucial (Kocisova, 2015, p. 198).

Upon examining the literature, it is seen that there are studies that tried to measure the soundness and financial stability of the banking sector in Turkey and other countries utilizing the endogeneous and macroeconomic variables related to the banking sector. In his study, Albulescu (2008) developed an index utilizing the quarterly data obtained over the period 19972007 to measure Romania's financial stability and soundness. The variables were normalized with the min-max normalization technique and factor analysis was conducted by equally weighting the sub-indexes. The study concluded that the index values and the reports published by the Romanian central bank were compatible. Morris (2010) developed a financial stability index for Jamaica using banking sector data in his study. In the study, the data obtained over the period 1997-2010 were normalized with the min-max normalization technique. The Z-score and Monte Carlo simulation methods were used to create the index. As a result of the study, it was determined that the indicators were sensitive to change during the periods through which the financial stability of Jamaica deteriorated. Sensoy, Öztürk and Hacihasanoğlu (2014) developed an index using the monthly data obtained over the period 2006-2014 to measure Turkey's financial fragility. The principal component analysis and dynamic conditional correlations method were employed to create the index. As a result of the study, it was asserted that the financial shocks from the USA boosted the financial fragility of Turkey more dramatically than the shocks from the Eurozone. Karanovic and Karanovic (2015) developed a financial stability index for the Balkan countries. The variables were normalized with the min-max normalization technique and factor analysis was conducted by equally weighting the sub-indexes. The study 
concluded that there were deteriorations in the stability index during the periods through which economic conditions deteriorated. Varlık and Varlık (2016) developed a banking system soundness index for Turkey utilizing the monthly data obtained over the period 2004-2015 and examined the impact of risk perception towards Turkey on the index. The principal component analysis method was employed to create the index. In the study, they concluded that the increase in risk perception adversely affected the balance sheet structure of the banking system. Sanar and Kara (2016) generated an index utilizing quarterly data obtained over the period 2007-2015 to measure Turkey's financial stability. Factor analysis and equal weighting method were conducted in the study. As a result of the study, they concluded that the index values were compatible with the economic developments in Turkey. Aksu, Sakarya and Aksu (2018) investigated the relationship between Turkey's financial stability and foreign direct investment inflows. In order to measure financial stability, they generated an index utilizing quarterly data obtained over the period 2007-2015. The variables were normalized employing the min-max normalization technique and factor analysis was performed by equally weighting the sub-indices of the index. As a result of the study, they determined that a unilateral causal relationship existed running from foreign direct capital inflows to financial stability. Chadwick and Öztürk (2019) aimed at developing a financial stress index for Turkey by utilizing the weekly data obtained over the period 2005-2016. The principal component analysis, portfolio theory, and Bayesian dynamic factor model were used to develop the index. It was determined that the developed index accurately pointed out the financial stress periods of Turkey.

In the literature, it is seen that there are studies that employed econometric models as well as other measurement methods without developing an index to measure financial soundness and financial stability. Ioannidis, Fotios and Zopounidis (2010) evaluated banking soundness using classification techniques. 944 banks from 78 countries were examined in the study. As a result of the study, three bank groups such as strong, sufficient, and weak were formed. Bourkhis and Nabi (2013) evaluated the impact of the financial crisis of 2007-2008 on the soundness of Islamic banks and commercial banks. In the study, Z-score and regression analysis were conducted on 34 Islamic and commercial banks of 16 countries. According to the results of the study, no significant difference in the impact of the financial crisis on Islamic banks and commercial banks was determined. Camelia and Angela (2013) investigated the financial soundness of banks operating in Central and Eastern Europe. The CAMELS and Z-score analyses were performed on 40 commercial banks. The study concluded that most of the banks with high soundness ratios were subsidiaries of major European banking groups. Kasselaki and Tagkalakis (2014) examined the relationship between financial soundness indicators and financial crisis utilizing various macroeconomic and financial variables. The research study, which was conducted in OECD countries, used regression analysis and a two-step GMM estimation method. According to the results of the study, it was concluded that an increase existed in capital risk-weighted assets and the quality of the assets plunged during crisis periods. Ashraf and Tariq (2016) investigated the financial soundness of the banks listed on the Pakistan Stock Exchange using the Bankometer model compared to the Z-score model. In the study, the Bankometer and Z-score models were employed for the variables over the period 2006-2014. According to the findings of the study, both models were detected to yield similar results. Rahman (2017) examined the financial soundness of commercial banks operating in Bangladesh. In the study, the Bankometer model was employed for the variables over the period 2010-2015. The study concluded that the banking sector in Bangladesh was in a financially 
positive position throughout the period 2010-2015. Koç and Karahan (2017) aimed to determine the determinants of financial soundness in the Turkish banking sector. Employing the panel regression model, the study concluded that asset quality, non-interest income, net asset profitability and liquidity were found as the determinants of financial soundness. Bae (2019) analyzed the financial soundness of the savings banks operating in South Korea. The panel fixed effects model was used in the study and it was concluded that the credit structures of the savings banks in South Korea were not effective. Talibong and Simiyu (2019) examined the financial soundness of microfinance banks operating in Kenya. In the study, the variables over the period 2012-2017 were analyzed employing the panel data regression method. In the study, it was concluded that the financial performances of the microfinance banks were good in terms of capital adequacy, asset quality, liquidity, and investment growth. Rashid (2021) compared the financial stability of countries with both Islamic and commercial banks and that of the countries with only commercial banks. In the study, 416 banks selected from 39 countries over the period 1995-2014 were analyzed using the panel data regression method. The study concluded that financial stability was higher in countries with both banking systems compared to the countries that preferred a single banking system.

In the international literature, it is also seen that studies were conducted to measure the soundness and financial stability of the banking sector by utilizing the indicators in the core set of the IMF. Maliszewski (2009) developed an index to measure the financial soundness of Poland. In the study, the index was measured by factor analysis of the quarterly data obtained over the period 1997-2009. As a result of the study, the developed indexes by using different weighting patterns yielded similar results in stability measurement. Cheang and Choy (2011) developed a financial stability index for the Macau banking system. The obtained data over the period 1996-2008 were normalized with the min-max normalization technique. In order to create the index, the variables were equally weighted and factor analysis was conducted. As a result of the study, it was observed that the stability index decreased during the crisis period. Arzamasov and Penikas (2014) developed a financial stability index for Israel. The obtained data over the period 2003Q1-2013Q3 were normalized with the min-max normalization method. The principal component analysis method was employed while developing the financial stability index. They concluded that the created index acted in accordance with the crisis periods. Kubiszewska (2018) developed a banking soundness index for Western Balkan countries and Baltic Sea countries. The Pentagon and CAMELS analyses were conducted for the data obtained over the period 2010 Q1-2016 Q1. As a result of the study, it was seen that the developed index for all countries acted in accordance with the crisis periods.

In the literature, it is seen that two main approaches based on indicators and models loomed large in measuring financial soundness and stability. In the indicator-based approach, only indicator sets were used as variables, or an index was developed by adding countryspecific macroeconomic variables to indicator sets. In the model-based approach, econometric models were established to measure financial soundness and stability. This study is conducted upon taking into account the indicator-based approach. This approach is adopted since the indicator-based approach has features such as high applicability and enabling cross-country comparisons. In the studies that adopted the indicator-based approach in the literature, it was seen that macroeconomic variables were mostly included in the indicator sets. Those studies aimed at determining the soundness and stability of the financial system in the country or countries. Unlike other studies, this study aims to develop a robustness index for the sector 
utilizing the variables that reflect the financial situation of the banking sector, which has been a single part of the financial system. In the literature, it is seen that Varlık and Varlık (2016) developed a banking soundness index for Turkey utilizing the variables pertinent to the balance sheet structure of the banking sector. Unlike the study, in order to create the banking soundness index, the indicator set related to the financial structure of the sector created by the IMF is taken into consideration in this study. The IMF financial soundness indicator set is used more widely than other indicator sets, by courtesy of its features such as being frequently used in model and indicator-based studies for the quantitative measurement of financial stability and vulnerabilities, its high applicability, ability of making comparisons among countries, and tracking its course over the years. The IMF's indicator set is created to help evaluate and monitor the strengths and weaknesses of the banking sector. Having a common indicator for countries is of great importance in terms of enabling comparisons among countries as well as tracking its progress over the years. Moreover, explaining the stages of principal component analysis for index development in detail, which is frequently used in the literature, is another redeeming feature that would be thought to contribute to the literature.

\section{Methodology}

Economic structures or systems, in general, consist of multidimensional variables. Analyzing the variables concurrently and analyzing the structure of the correlation or variancecovariance matrix of their properties are of great importance in studies that have been conducted using the multivariate analysis method. The principal component analysis method, one of the multivariate analysis methods, was developed by Hotelling (1933). The principal component analysis involves expressing the dataset which consists of original $\mathrm{p}$ variables new variables having fewer and linear components (Johnson and Wichern, 2002, p. 425). A maximum $\mathrm{p}$ number of basic components are obtained from a data matrix containing a $\mathrm{p}$ number of variables (Johnson, 2000, p. 271).

$$
\begin{aligned}
& P C_{1}=a_{11} X_{1}+a_{12} X_{2}+\cdots+a_{1 p} X_{p} \\
& P C_{2}=a_{21} X_{1}+a_{22} X_{2}+\cdots+a_{2 p} X_{p} \\
& P C_{p}=a_{p 1} X_{1}+a_{p 2} X_{2}+\cdots+a_{p p} X_{P}
\end{aligned}
$$

$P C_{1}, P C_{2}, \ldots, P C_{p}$ where $i$ denotes the number of principal components, and $j$ indicates the weight of the variable. The principal component weights $\left(a_{i j}\right)$ are calculated to fulfill the following conditions.

a) The first principal component contributes the most to the total variance, whereas the other component contributes to the total variance at gradually decreasing amounts.

$$
\begin{gathered}
a_{i 1}^{2}+a_{i 2}^{2}+\cdots+a_{i p}^{2}=1(\mathrm{i}=1,2, \ldots, \mathrm{p}) \\
a_{i 1}^{2} a_{j 1}^{2}+a_{i 2}^{2} a_{j 2}^{2}+\cdots+a_{i p}^{2} a_{j p}^{2}=0(\mathrm{i} \neq \mathrm{j})
\end{gathered}
$$

c)

In the principal component analysis, each component is calculated as a linear function of all components in the analysis. The resulting principal components make the maximum contribution to the total variance, respectively. According to the second case, the sum of the 
squares of the basic component weights should be equal to unity. In order to fulfill this condition, all variables in the analysis must be standardized.

Standardization, in other words, the normalization process ensures that the data of the variables are expressed in an order. In this process, each variable is standardized with a mean value of 0 and a standard deviation value of 1 . The Min-Max normalization technique, which has been frequently used in the literature, is employed in the study. In the Min-Max normalization technique, the largest and smallest values in the dataset of variables are considered. The normalization process is completed by assigning the highest value to 1 and the lowest value to 0 and assigning values according to this interval for all other data. The formula for the Min-Max normalization method is as follows (Petrovska and Mihajlovska, 2013, p. 9192).

$$
X^{n}=\frac{X_{i}-X_{\min }}{X_{\max }-X_{\min }}
$$

In the formula, $X^{n}$ represents the normalized data; denotes input value; $X_{\min }$ is the smallest number in the dataset, and $X_{\max }$ is the largest number in the dataset. Following the standardization of the variables, the weights in which the variables would take place in the formation of the index should be calculated. These weights are calculated by courtesy of the principal component analysis. The weights in the principal component analysis exhibit the impact of one standard deviation change in the variable on the index.

\section{Data Collection}

In the study, the banking soundness index for Turkey is tried to be generated by taking into account the core set of the IMF's financial soundness indicators. For this purpose, a total of 11 variables are utilized in the study that includes the quarterly data over the period 2007-2020.

The variables used in the study include the ratios of capital to risk-weighted assets, tier I capital to risk-weighted assets, non-performing loans net of provisions to capital, nonperforming loans to total gross loans, return on assets, return on equity, interest margin-to-gross income, non-interest expenses to gross income, liquid assets to total assets, liquid assets to short-term liabilities, and the net open position in foreign exchange to capital. The variables used in the study are obtained from the IMF's databank. In the study, capital adequacy, asset quality, profitability, liquidity, and market risk are categorized into sub-indicators in order to calculate the index. The sub-indicators and acronyms of the variables used in the study are presented in Table 1. 
Table 1. BSI Sub-indicators, Ratios, and Acronyms

\begin{tabular}{lll}
\hline BSI Sub-indicators & Acronym & Definition \\
\hline \multirow{3}{*}{ Capital Adequacy Ratio } & NRCRW & Regulatory capital to risk-weighted assets \\
& NRTRN & Regulatory Tier I capital to risk-weighted assets \\
& NPLC & Non-performing loans net of provisions to capital \\
\hline Asset Quality Ratio & NPL & Non-performing loans to total gross loans \\
\hline \multirow{2}{*}{ Profitability Ratio } & NROA & Return on assets \\
& NROE & Return on equity \\
& NIM & Interest margin-to-gross income \\
\hline \multirow{2}{*}{ Liquidity Ratio } & NIG & Non-interest expenses to gross income \\
\hline Risk Ratio & NLATA & Liquid assets to total assets \\
\hline
\end{tabular}

Source: IMF (2021)

According to the core capital concept of the Basel committee on banking supervision, the indicators of the ratio of capital to risk-weighted assets and the ratio of Tier I capital to riskweighted assets measure the capital adequacy of depositors. The ratio of non-performing loans net of provisions to capital measures the possible impact of non-performing loans on capital. This indicator also shows the sector's repayment ability. The ratio of non-performing loans to gross loans indicates the problems related to the asset quality in the loan portfolio. Cyclical reasons as well as the fact that the bank follows a relatively flexible loan policy may account for the high level of non-performing loans, which represent non-performing loans that cannot be collected at maturity. Regardless of the reason, these non-performing loans would cause revenue loss for the bank. Return on assets and return on equity indicators show the efficiency of depositors in using their assets. Banks with high profitability are expected to be more comfortable in pricing, whereas banks operating at low profit margins are expected to apply competitive prices in order to attract more deposits and extend higher loans. Also, these indicators are considered as efficiency criteria for bank management. The ratio of interest margin-to-gross income is the indicator of net interest earnings in gross income. The ratio of non-interest expenses to gross income indicates the relative share of non-interest expenses in gross income. The ratio of liquid assets to short-term liabilities indicates the level of liquidity required to meet short-term liabilities. The ratio of a net open position in foreign exchange to capital indicates the fragility of the sector. In the case of currency depreciation, it measures the size of the pressure on banks (IMF, 2006, p. 77-82).

\section{Results}

In the study, a normalization procedure is employed for each of the previously stated ratios in order to generate the banking soundness index. The min-max normalization technique is used and each variable is standardized as having the mean value of 0 and the standard deviation of 1. Descriptive statistics of sub-indicators of the banking soundness index are presented in Table 2 following the normalization of the variables. 
Table 2. Descriptive Statistics of the Variables

\begin{tabular}{lccccc}
\hline Variables & Mean & Median & Std. Dev. & Skewness & Kurtosis \\
\hline NRCRW & 0.443240 & 0.395709 & 0.244846 & 0.399123 & 2.148883 \\
NRTRN & 0.449405 & 0.380927 & 0.276050 & 0.516587 & 2.032648 \\
NPLC & 0.296793 & 0.232074 & 0.223095 & 1.324665 & 4.528284 \\
NPL & 0.317817 & 0.193716 & 0.294100 & 1.021110 & 2.774795 \\
NROA & 0.395382 & 0.345487 & 0.307304 & 0.585506 & 2.106387 \\
NROE & 0.402878 & 0.378753 & 0.288452 & 0.529987 & 2.275194 \\
NIM & 0.497728 & 0.486730 & 0.242064 & 0.057510 & 2.406862 \\
NIG & 0.520263 & 0.508217 & 0.268387 & -0.082944 & 2.275247 \\
NLATA & 0.483181 & 0.463638 & 0.214948 & 0.100917 & 2.533225 \\
NLAST & 0.607688 & 0.644854 & 0.248041 & -0.534253 & 2.531623 \\
NOPFC & 0.527951 & 0.548391 & 0.231340 & -0.105482 & 2.457718 \\
\hline
\end{tabular}

According to the descriptive statistics presented in Table 2, it is seen that the mean and median values of the variables are generally convergent. Upon considering the standard deviation values, it is seen that the highest value belongs to the NROA variable. This indicates that the ratio with the furthest distribution involves the NROA variable.

The kurtosis of the distribution ranges between 2.03 and 4.52, indicating that the distribution has an asymmetrical feature. In the skewness values, the negative situation indicates that the distribution is right-tailed, whereas the positive situation indicates that the distribution is left-tailed. The skewness values of the variables are found to be positive in general.

Prior to conducting principal components analysis, the correlation relationships among the variables are investigated. The correlation coefficients among the sub-indicators of the banking soundness index are presented in Table 3.

Table 3. BSI Correlations Among the Variables

\begin{tabular}{|c|c|c|c|c|c|c|c|c|c|c|c|}
\hline & $\stackrel{\Xi}{\mathbf{Z}}$ & $\bar{Z}$ & 哺 & 岁 & $\begin{array}{l}0 \\
\frac{1}{2} \\
0 \\
Z\end{array}$ & $\overrightarrow{\mathbf{z}}$ & $\frac{U}{\vec{Z}}$ & 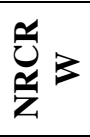 & 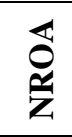 & $\begin{array}{l}\text { 됭 } \\
\text { 劣 }\end{array}$ & 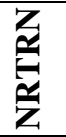 \\
\hline NIG & 1.00 & & & & & & & & & & \\
\hline NIM & -0.11 & 1.00 & & & & & & & & & \\
\hline NLAST & 0.22 & -0.49 & 1.00 & & & & & & & & \\
\hline NLATA & 0.08 & -0.41 & 0.92 & 1.00 & & & & & & & \\
\hline NOPFC & -0.30 & 0.27 & -0.10 & -0.05 & 1.00 & & & & & & \\
\hline NPL & -0.50 & 0.12 & 0.03 & 0.22 & 0.22 & 1.00 & & & & & \\
\hline NPLC & -0.46 & 0.45 & -0.60 & -0.43 & 0.24 & 0.52 & 1.00 & & & & \\
\hline NRCRW & -0.41 & -0.07 & 0.31 & 0.44 & 0.11 & 0.75 & 0.03 & 1.00 & & & \\
\hline NROA & -0.06 & -0.47 & 0.72 & 0.71 & -0.02 & 0.25 & -0.62 & 0.60 & 1.00 & & \\
\hline NROE & -0.12 & -0.44 & 0.69 & 0.68 & 0.02 & 0.23 & -0.61 & 0.57 & 0.98 & 1.00 & \\
\hline NRTRN & -0.15 & -0.28 & 0.55 & 0.63 & -0.05 & 0.57 & -0.29 & 0.90 & 0.81 & 0.77 & 1.00 \\
\hline
\end{tabular}

Upon examining Table 3, it is seen that the highest correlations exist between NROA and NROE; between NRCRW and NRTRW; and between NLATA and NLAST. The certain levels of the correlations among the sub-indicators of the banking soundness index indicate a high probability of generating a common factor among the sub-indicators. The Kaiser criteria are employed to determine the number of components in principal component analysis. According to the Kaiser criterion, depending on the statistical feature of the dataset, it is generally 
recommended to accept all factors with eigenvalues exceeding 1 in factor selection (Kaiser, 1960). Each unaccepted factor means that less of the common variance is explained. Table 4 presents the total variance explained of the used variables according to the basic components.

Table 4. Eigenvalues of the Principal Components

\begin{tabular}{lccccc}
\hline Number & Value & Difference & Proportion & $\begin{array}{c}\text { Cumulative } \\
\text { Value }\end{array}$ & Cumulative Proportion \\
\hline 1 & 5.121452 & 2.335457 & 0.4656 & 5.121452 & 0.4656 \\
2 & 2.785994 & 1.830212 & 0.2533 & 7.907446 & 0.7189 \\
3 & 0.955782 & 0.199018 & 0.0869 & 8.863228 & 0.8057 \\
4 & 0.756764 & 0.100878 & 0.0688 & 9.619992 & 0.8745 \\
5 & 0.655886 & 0.243319 & 0.0596 & 10.27588 & 0.9342 \\
6 & 0.412566 & 0.222377 & 0.0375 & 10.68844 & 0.9717 \\
7 & 0.190189 & 0.132576 & 0.0173 & 10.87863 & 0.9890 \\
8 & 0.057614 & 0.018716 & 0.0052 & 10.93625 & 0.9942 \\
9 & 0.038897 & 0.019053 & 0.0035 & 10.97514 & 0.9977 \\
10 & 0.019844 & 0.014832 & 0.0018 & 10.99499 & 0.9995 \\
11 & 0.005011 & --- & 0.0005 & 11.00000 & 1.0000 \\
\hline
\end{tabular}

According to Table 4, the variances of merely 2 out of 11 variables used in the model are higher than unity. The cumulative ratio indicates the ratio at which the principal components explain the total variances of the variables. Two principal components with variances higher than unity explain approximately $72 \%$ of the total variance. The banking soundness index is be formed by weighting according to the variance explanation ratio so that the sum of the weights of two components is equal to unity. The eigenvectors associated with each of the principal components are presented in Table 5.

Tablo 5. Eigenvectors of the Principal Components

\begin{tabular}{lcr}
\multicolumn{3}{c}{ Tablo 5. Eigenvectors of the Principal Components } \\
& $\begin{array}{c}\text { PCA: Eigenvectors (loadings) } \\
\text { Sample: 2007: Q2 - 2020: Q3 }\end{array}$ \\
\hline Variables & PC 1 & \multicolumn{1}{c}{ PC 2 } \\
\hline NIG & -0.017397 & -0.450556 \\
NIM & -0.231818 & 0.238297 \\
NLAST & 0.366545 & -0.186649 \\
NLATA & 0.372958 & -0.065330 \\
NOPFC & -0.031309 & 0.270023 \\
NPL & 0.143543 & 0.513212 \\
NPLC & -0.250361 & 0.427788 \\
NRCRW & 0.302015 & 0.380709 \\
NROA & 0.422081 & -0.013028 \\
NROE & 0.410039 & -0.004309 \\
NRTRN & 0.388255 & 0.191517 \\
\hline
\end{tabular}

In the principal component analysis, eigenvalues indicate the extent to which general information would be extracted from each principal component. Eigenvectors indicate the extent to which each variable weights each component. A positive value for the principal component indicates that there is the same directional relationship, whereas a negative value indicates the presence of an opposite directional relationship. Moreover, the square of factor loadings indicates the extent to which a variable explains the variance in a factor. According to Table 5, 
the variables with the highest factor loadings in the first eigenvector are NROA (42\%), NROE (41\%), NRTRN (39\%), and NLATA (37\%), respectively. NROA, NROE, NRTRN, and NLATA explain approximately 19\%, 18\%, 16\%, and 15\% of the variance in the first eigenvector, respectively. The variables with the highest factor loadings in the second eigenvector are NPL (51\%), NIG (- 45\%), NPLC (43\%), and NRCRW (38\%), respectively. NPL, NIG, NPLC, and NRCRW explain approximately $28 \%, 22 \%, 18 \%$, and $16 \%$ of the variance in the second eigenvector, respectively. In Figure 1, the basic directions among the variables are illustrated in the Orthonormal Loadings chart.

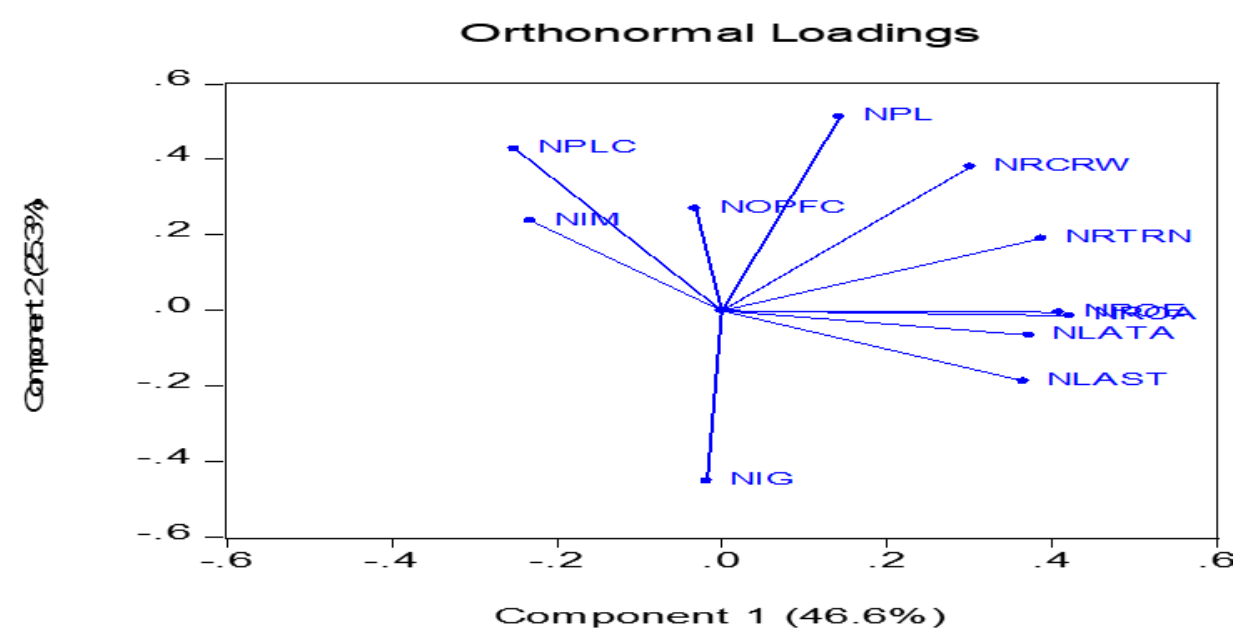

Figure 1. Orthonormal Loadings

According to Figure 1, NROA, NROE, and NLATA variables are in a strong relationship in the first main component. In the second main component, it can be claimed that NPLC, NIM, and NOPFC variables are in a strong relationship. According to the Orthonormal Loadings plot, it is seen that a negative correlation exists between NPL, NRCRW, NRTRN, NROA, NROE, NLATA, NLAST variables, and the NOPFC, NIG, NIM, NPLC variables. Besides, it can be claimed that these variables are almost unrelated to NIG variable since an angle exceeding 90 degrees occurs between NRTRN, NRCRW, NPL variables, and NIG variable. It is subjected to a rotation for the interpretation of the basic components and to provide significance. Although rotation does not change the basic mathematical properties of the solution, it increases the loading of the items on a factor. In this case, a decrease in the loading on other factors is observed and the factors can be interpreted more easily. The Varimax method is the most commonly employed method for numerical data. Rotation results according to the Varimax technique are presented in Table 6. 
Tablo 6. Rotation-Factor Matrix

\begin{tabular}{lrr}
\multicolumn{3}{c}{$\begin{array}{c}\text { Rotation Method: Orthogonal Varimax } \\
\text { Kaiser row weighting }\end{array}$} \\
\hline Variables & Factor 1 & Factor 2 \\
\hline NIG & 0.046327 & -0.688239 \\
NIM & -0.506978 & 0.270897 \\
NLAST & 0.853419 & -0.221736 \\
NLATA & 0.840919 & -0.017273 \\
NOPFC & -0.100363 & 0.328769 \\
NPL & 0.214946 & 0.890275 \\
NPLC & -0.647234 & 0.656308 \\
NRCRW & 0.600108 & 0.722405 \\
NROA & 0.958414 & 0.080319 \\
NROE & 0.929675 & 0.088285 \\
NRTRN & 0.834124 & 0.430260 \\
\hline
\end{tabular}

Upon examining the matrix factor according to Table 6, the first principal component receives $95.8 \%, 92.9 \%, 85.3 \%$, and $84 \%$ positive information from NROA, NROE, NLAST, and NLATA, respectively. The second principal component, however, receives $89 \%, 72.2 \%$, and $65 \%$ positive information from NPL, NRCRW, and NPLC, whereas receives $68.8 \%$ negative information from NIG.

At the last stage of the principal component analysis, the weights of the rotated principal component matrix are determined, considering that the total variance explained of each principal component in all factors has an equal share to the regained variance ratio. Matrix weights of the banking soundness index are calculated as follows (PC1 46.56\%, PC2 25.33\%).

$$
B S I=\frac{46.56}{71.89} P C 1+\frac{25.33}{71.89} P C 2
$$

After determining the weights of the sub-indicators with factor analysis, the sub-indicator set is generated by multiplying the values of the banking soundness index ratios with the weights. All the variables in the components presented in Table 7 are weighted according to their factor loads.

Table 7. Weighting of Index Components

\begin{tabular}{lc}
\hline Variables & Weights \\
\hline NIG & 0.16 \\
NIM & 0.06 \\
NLAST & 0.17 \\
NLATA & 0.22 \\
NOPFC & 0.07 \\
NPL & 0.27 \\
NPLC & 0.01 \\
NRCRW & 0.32 \\
NROA & 0.27 \\
NROE & 0.26 \\
NRTRN & 0.31 \\
\hline
\end{tabular}

Then, the sub-indicator values are summed up and the quarterly banking soundness index values over the period $2007-2020$ are calculated. The time graph of the index obtained by the principal component analysis is illustrated in Figure 2. 


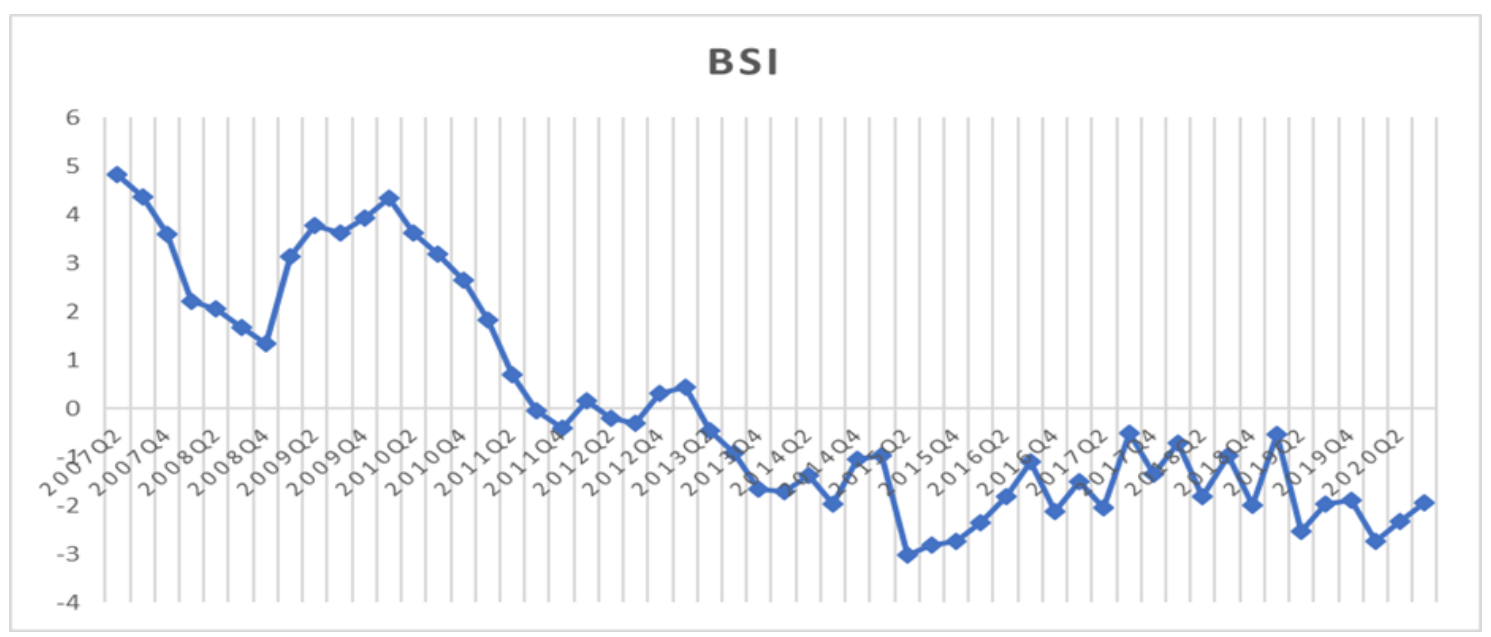

Figure 2. Turkey's BSI - Time Graph

Upon analyzing Figure 2, it is seen that the highest value was reached in the second quarter of 2007 within the interval in which the index was calculated. According to the financial stability report published by the CBRT in 2007, it was stated that the banking system in Turkey grew and its profitability increased in the first half of 2007. Globally, the problems experienced in the mortgaged housing finance markets in the USA increased the concerns about financial stability by the end of 2007. The global crisis, which broke out in the USA as of 2008 and also affected Europe and Asia, increased the volatility in the markets and had a negative impact on the financial indicators. In order to reduce the impact of the volatility in financial markets and to maintain liquidity support to the banking sector, the FED initiated a monetary expansion (QE1) and lowered interest rates. In order to prevent international fluctuations in the CBRT, borrowing and lending interest rates were lowered. Interest rate cuts persisted gradually until the second quarter of 2009 in order to maintain the expectation of a decreased inflation and liquidity support to the banking sector. Moreover, required reserve ratios were reduced in order to ensure permanent liquidity to the banking system. In 2011, when the index plunged rapidly, the central bank increased the required reserves significantly, which caused the withdrawal of liquidity in the banking sector. Furthermore, the depreciation of the Turkish lira was reflected negatively on the soundness index. The five-item economic action plan published in the last quarter of 2011 was reflected positively on the index and prevented long-term negativities from occurring for the index. Decreases were observed in the banking soundness index by the third quarters of 2013,2014 , and 2015. The aggravated volatility in exchange rates and interest rates throughout these periods caused a limited decline in the index. The FED's decision of hiking interest rates in 2015 and the slowdown in the Chinese economy caused financial concerns on a global scale. In Turkey, however, the two elections held as of 2015 as well as the rise in geopolitical risks negatively affected the index. The index reached its first trough in the third quarter of 2015. The index followed a fluctuating course over the period 2016-2019. The index reached its second trough in the first quarter of 2020. The coronavirus pandemic, which emerged in China in the last quarter of 2019 and spread rapidly in Turkey and European countries in the first quarter of 2020, negatively affected the banking soundness index. The pandemic-induced volatility and negative expectations in financial markets increased. In the first quarter of 2020, the contractionary global financial conditions and the negative impacts of the pandemic on sectors resulted in partial deterioration of banks' financial structure. The CBRT's interest rate cuts in 
the third quarter of 2020 caused a rise in credit volumes in the banking sector. The rapid increase in credits was supported by deposit growth. This situation had a positive impact on the index.

\section{Conclusion and Discussion}

The banking sector constitutes a large portion of the financial markets. Along with the increase of financial integration, the banking sector has great importance globally due to its functions in the economy. Banks must acquire a strong financial structure in the presence of various risks stemming from the balance sheet and off-balance sheet items. The fact that banks do not have a solid and stable structure may cause serious problems in the banking system, as well as it may affect the real sector and lead the country's economy to a crisis. The starting point of this study is to generate a banking soundness index for Turkey by adapting the core set of financial stability index created by the IMF to the conditions and data of Turkey. In this context, the changes in the current literature are taken into consideration in terms of fostering the study, and it is aimed to develop the banking soundness index by examining the composite index creation methods.

In the study, the financial stability index of the IMF is divided into several sub-indicators such as capital adequacy, asset quality, profitability, liquidity, and market risk. The quarterly data obtained over the period 2007-2020 are utilized in the index. The variables in the subindicators are standardized employing the min-max normalization method. The banking soundness index is generated by conducting a principal component analysis on the standardized data. According to the findings obtained from the study, the variables are categorized into two principal components.

It is concluded that in the first principal component, NROA, NROE, and NLATA variables are in a strong relationship. Upon considering in terms of sub-indicators related to the first principal component, it is seen that profitability and liquidity ratios are in a strong relationship in the first principal component. In the second principal component, however, NPLC, NIM, and NOPFC variables are in a strong relationship. In terms of sub-indicators, it is seen that a relationship exists between the risk ratio and certain capital adequacy as well as profitability ratios. Upon examining the results of the index generated in the study, the Turkish banking soundness index reached its highest value in the second quarter of 2007. Upon examining the financial stability reports prepared by the CBRT for this period, it is seen that stability has been achieved in the Turkish banking sector. The index reached its lowest levels by the third quarter of 2015 and the first quarter of 2020. According to the financial stability reports, it is observed that there have been periods of declined stability in the banking sector due to the increased fear and anxiety in the markets regarding the economy.

The results obtained from the study were previously reported by Sanar and Kara (2016) who developed financial soundness, financial stability, and financial fragility indexes, Chadwick and Öztürk (2018), Aksu et al. (2018) and were partially similar to the findings of Varlık and Varlik (2016). The periodic differences in the studies and the differences in the variables used upon generating the index are thought to account for such a difference. It is thought that the increase in the diversity of the variables under the indicators used as the basis 
for measuring financial soundness would reflect the periodic movements better and determine the financial status of the sector more accurately.

According to the findings of the study, within the framework of policies that can aggravate the banking soundness index, both (a) the maintenance of regulatory and supervisory activities to protect the soundness of the banking sector's financial structure and (b) implementation of policies supporting macro-financial stability that would limit the increases in Turkey's geopolitical risks, exchange rate risk, interest rate risk, and country risk premium may be suggested to the sector regulators.

The limitations of the study involve the fact that the indicators based on the study are obtained from the official website of the IMF and the data regarding Turkey starts by the second quarter of 2007. Therefore, it can be claimed that there are period constraints regarding variables in the study. Furthermore, it can be claimed that a country restriction exists, since the banking soundness index was merely generated for Turkey in the study. In future studies, it may be suggested to make a comparison by calculating the banking soundness indexes of different countries.

\section{Researcher's Contribution Rate Statement}

I am a single author of this paper. My contribution is $100 \%$.

\section{Conflict of Interest Statement}

There is no potential conflict of interest in this study. 


\section{References}

Aksu, M., Sakarya, Ş. and Aksu, S. (2018). Finansal istikrar ile doğrudan yabancı sermaye girişleri arasındaki ilişkinin analizi: Türkiye ekonomisinde bir uygulama [Anaylsis of the relationship between financial stability and foreign direct inflows: An analysis on the economy of Turkey] [Special issue]. Anemon Muş Alparslan Üniversitesi Sosyal Bilimler Dergisi, 6, 195-200. doi:10.18506/anemon.453876

Albulescu, C. T. (2008). Assessing Romanian financial sector stability: the importance of the international economic climate (MPRA Working Paper No. 16581). Retrieved from https://mpra.ub.uni-muenchen.de/16581/1/MPRA_paper_16581.pdf

Arzamasov, V. and Penikas, H. (2014). A financial stability index for Israel. Procedia Computer Science, 31, 985- 994. doi: 10.1016/j.procs.2014.05.351

Ashraf, A. and Tariq, Y. B. (2016). Evaluating the financial soundness of banks: An application of bankometer on Pakistani listed banks. IUP Journal of Financial Risk Management, 13(3), 47- 63. Retrieved from https://web.p.ebscohost.com/

Bae, S. H. (2019). A study on determinants of financial soundness of savings banks. The Journal of the Convergence on Culture Technology, 5(4), 277-282. doi:10.17703/JCCT.2019.5.4.277

Bourkhis, K. and Nabi, M. S. (2013). Islamic and conventional banks' soundness during the 2007-2008 financial crisis. Review of Financial Economics, 22(2), 68-77. doi:10.1016/j.rfe.2013.01.001

Camelia, Ș. A. and Roman, A. (2013). A cross-country analysis of the banks' financial soundness: The case of the CEE-3 countries. Annals of the University of Oradea: Economic Science Series, 22(1), 357-367. Retrieved From http://anale.steconomiceuoradea.ro/

Chadwick, M. G. and Ozturk, H. (2019). Measuring financial systemic stress for Turkey: A search for the best composite indicator. Economic Systems, 43(1), 151-172. doi:10.1016/j.ecosys.2018.09.004

Cheang, N. and Choy, I. (2011). Aggregate financial stability index for an early warning system. Macao Monetary Research Bulletin, 21(1), 27-51. Retrieved from https://www.amcm.gov.mo/en/research-statistics/research-and-publications

Čihák, M. (2007). Systemic loss: a measure of financial stability. Czech Journal of Economics and Finance, 57(1), 5-26. Retrieved from https://journal.fsv.cuni.cz

Gadanecz, B. and Jayaram, K. (2008). Measures of financial stability- A review. Irving Fisher Committee Bulletin, 31(1), 365-383. Retrieved from https://www.bis.org/ifc_bulletins

Hotelling, H. (1933). Analysis of a complex of statistical variables into principal components. Journal of Educational Psychology, 24(6), 417. doi:10.1037/h0071325

International Monetary Fund. (2006). Financial soundness indicators compilation guide. Retrieved from https://www.imf.org/external/pubs/ft/fsi/guide/2006/index.htm

Ioannidis, C., Fotios P. and Zopounidis, C. (2010). Assessing bank soundness with classification techniques. Omega, 38(5), 345-357. doi:10.1016/j.omega.2009.10.009

Johnson, J. W. (2000). Factor analysis of importance ratings in job analysis: Note on the misinterpretation of Cranny and Doherty. Organizational Research Methods, 3(3), 267-284. doi:10.1177/109442810033004

Johnson, R. A. and Wichern, D. W. (2002). Applied multivariate statistical analysis. New Jersey: Prentice Hall Inc.

Kaiser, H. F. (1960). The application of electronic computers to factor analysis. Educational and Psychological Measurement, 20(1), 141-151. doi:10.1177/001316446002000116

Karanovic, G. and Karanovic, B. (2015). Developing an aggregate index for measuring financial stability in the Balkans. Procedia Economics and Finance, 33, 3-17. doi:10.1016/S2212-5671(15)01690-1

Kasselaki, M. T. and Tagkalakis, A. O. (2014). Financial soundness indicators and financial crisis episodes. Annals of Finance, 10(4), 623-669. doi:10.1007/s10436-013-0233-6 
Koç, Y. D. and Karahan, F. (2017). Türk bankacılık sektöründe finansal sağlamlığın belirleyicileri [Financial stability indicators of Turkish banking sector]. International Journal of Academic Value Studies, 3(15), 148-153. doi:10.23929/javs.566

Kočišová, K. (2015, October). Banking stability index: A cross-country study. Paper presented at the 15 th International Conference on Finance and Banking. Czech Republic. Retrieved from http://icfb2015.cms.opf.slu.cz/sites/icfb.rs.opf.slu.cz/files/kocisova.pdf

Kubiszewska, K. (2018). Interdependence of ratios in banking stability pentagon. Studia $i$ Materiaty, 28(2), 65-79. doi:10.7172/1733-9758.2018.28.6

Maliszewski, K. (2009, October). Measuring stability of the Polish financial system by means of a synthetic index. Paper presented at the 12th International Conference on Finance and Banking: Structural and Regional Impacts of Financial Crises. Czech Republic. Retrieved from https://citeseerx.ist.psu.edu/viewdoc/download?doi=10.1.1.508.1174\&rep=rep1\&type=pdf

Morris, V. (2010). Measuring and forecasting financial stability: The composition of an aggregate financial stability index for Jamaica. Bank of Jamaica, 6(2), 34-51. Retrieved From https://boj.org.jm/boj-publications/boj-publication-archive

Petrovska, M. and Mihajlovska, E. M. (2013). Measures of financial stability in Macedonia. Journal of Central Banking Theory and Practice, 2(3), 85-110. Retrieved From https://sciendo.com/journal/JCBTP

Pukhov, V. I. (2013). Formation of financial stability management system of commercial banks (Unpublished doctoral dissertation). State Management University, Moscow, Russia.

Rahman, Z. (2017). Financial soundness evaluation of selected commercial banks in Bangladesh: An application of bankometer model. Research Journal of Finance and Accounting, 8(2), 63-70. Retrieved From https://core.ac.uk/

Rashid, A. (2021). Financial soundness of single versus dual banking system: Explaining the role of Islamic banks. Portuguese Economic Journal, 20(1), 99-127. doi:10.1007/s10258-019-00171-2

Sanar, F. and Kara, M. (2016). Finansal istikrar kavramı ve Türkiye için finansal istikrar endeksi önerisi [The concept of financial stability and financial stability index for Turkey]. Ekonomik Yaklaşım, 27(101), 111-160. doi:10.5455/ey.35950

Sensoy, A., Özturk, K. and Hacihasanoglu, E. (2014). Constructing a financial fragility index for emerging countries. Finance Research Letters, 11(4), 410-419. doi:10.1016/j.frl.2014.07.007

Talibong, J. K. and Simiyu, E. M. (2019). Financial soundness indicators and financial performance of deposit taking micro finance banks in Kenya. African Journal of Emerging Issues, 1(11), 67-84. Retrieved From https://ajoeijournals.org

Varlık, N. and Varlık, S. (2016). Risk algısının Türkiye'de bankacılık sektörüne etkileri: Bankacılık sağlamlık endeksi ile bir değerlendirme [The effects of risk perception on banking sector in Turkey: An assessment with banking system soundness index]. Yönetim ve Ekonomi Dergisi, 23(2), 545-563. doi:10.18657/yecbu.20029 